AperTO - Archivio Istituzionale Open Access dell'Università di Torino

\title{
Corporate governance and financial performance for engaging socially and environmentally responsible practices
}

\section{This is the author's manuscript}

Original Citation:

Availability:

This version is available http://hdl.handle.net/2318/1666153

since 2021-12-20T10:47:52Z

Published version:

DOI:10.1108/SRJ-12-2017-0276

Terms of use:

Open Access

Anyone can freely access the full text of works made available as "Open Access". Works made available under a Creative Commons license can be used according to the terms and conditions of said license. Use of all other works requires consent of the right holder (author or publisher) if not exempted from copyright protection by the applicable law. 


\title{
Corporate governance and financial performance for engaging socially and environmentally responsible practices
}

\author{
Simona Fiandrino, Alain Devalle and Valter Cantino
}

\begin{abstract}
Purpose - This paper aims to reconcile the conflicting understanding on the nexus between corporate governance (CG), corporate financial performance (CFP) and corporate social responsibility (CSR) by investigating how companies engage with CSR practices.
\end{abstract}

Design/methodology/approach - The study carries out a multivariate linear regression analysis on a sample of 361 listed companies from five countries in Europe: France, Germany, Italy, Spain and the UK.

Findings - CG mechanisms and CFP have an impact on CSR because they affect social and environmental practices strongly and significantly. Furthermore, the findings describe the capacity of CSR to influence both the CG structure and the CFP.

Research limitations/implications - The present research limits the analysis on the social and environmental performance of companies that communicate their commitment to stakeholders without distinguishing between "greenwashing" companies that implement CSR to improve corporate reputation and those companies that pursue effective societal benefits, taking care of stakeholder relationships.

Practical implications - The CSR approach can drive the CG structure and improve CFP if managers perceive the implementation of sustainable practices as an integrated process rather than a mere outcome.

Originality/value - This paper seeks to disentangle the nexus between CG, CFP and CSR, not yet precisely defined by scholars in the context of five countries in Europe.

Keywords Corporate social responsibility, CSR, Europe, Sustainability,

Corporate financial performance, Corporate governance

Paper type Research paper

\section{Introduction}

Corporate social responsibility (CSR) is based on the concept that business should go beyond enhancement of socially responsible actions (Croker and Barnes, 2017). The European Commission defines CSR as "actions by companies over and above their legal obligations toward society and the environment" (European Commission, 2011, p. 3). As a matter of fact, during the past decades, the planet has registered a scarcity of tangible resources due to extensive overconsumption, and there has also been a rise of social iniquities along with steady economic growth (Rezaee, 2017). Hence, fostering of social and environmental responsibility in order to deliver sustainable outcomes and the inclusion of social and environmental practices into business processes is likely to become increasingly necessary. Therefore, companies are calling for the imperative need to go beyond mere corporate financial performance (CFP) and shortage results by integrating economic, social and environmental objectives into the core of their business activities. Two main promising challenges are at the forefront in the CSR discourse. First, companies should align economic sustainability alongside environmental and social sustainability "by re-allocating
Simona Fiandrino is a PhD Candidate at the Department of Management, University of Turin, Italy. Alain Devalle is an Associate Professor and Valter Cantino is Professor, both at the Department of Management, University of Turin, Italy.

Received 23 December 2017 Revised 5 March 2018 Accepted 18 March 2018

The authors gratefully appreciated the helpful comments and suggestions received from $\mathrm{R}$. Edward Freeman and from the anonymous reviewers. 
their financial or in-kind resources into their business processes" (Tonello and Singer, 2015, p. 1). Second, companies should reconsider their business processes "by being farsighted and planning ahead in order to minimize social and environmental harm" (Nidumolu et al., 2015, p. 2).

Scholarly research has increasingly investigated the evolution of CSR concepts (Croker and Barnes, 2017), and it has addressed which factors strengthen the inclusion of CSR activities within the core of business processes (Cullinan et al., 2016). The literature identifies the role of corporate governance (CG) (Jamali et al., 2008; Tuan, 2012) and the usefulness of financial resources and CFP (Surroca et al., 2010; Perrini et al., 2012) as primary motifs for implementing CSR practices. However, the current literature has struggled around the relation between CG, CFP and CSR and offers no definitive answers thus far. In more detail, some academic studies propose further investigation into the intersection of CG and CSR (Aguilera et al., 2006; Jain and Jamali, 2016), and more clarity on the relationship between CFP and CSR is still needed (Revelli and Viviani, 2015). Recently, Wang and Sarkis (2017) investigated the impact of CSR outcomes and CSR governance on CFP with an attempt to demonstrate whether CSR performance mediates the link between CSR governance and CFP. Results show that financial results are substantially higher only if the CSR governance structure ensures the use of effective management systems to seriously develop CSR issues.

Following this stream of research, this study contributes to the debate by seeking to understand the role of CG and CFP in social and environmental practices through the examination of a sample of 361 listed companies from five countries in Europe.

The aim of the study is twofold. First, it seeks to disentangle the nexus between CG, CFP and CSR that is not precisely defined by scholars by understanding to what extent companies address sustainable practices and deliver sustainability programs and activities. Second, it seeks to understand the level of CSR practices in five countries in Europe in light of the Directive 2014/95/EU that calls for more transparency of undertakings' non-financial information and consequently, companies should be aligned and compliant with the regulation.

To accomplish the aforementioned objectives, the research empirically carries out a multivariate regression analysis considering companies from France, Germany, Italy, Spain and the UK whose environmental, social and governance (ESG) data from DataStream were available for the year 2016.

The structure of the paper is organized as follows. In Section 2, previous academic works on the nexus between CG, CFP and CSR are illustrated, the literature review supports the research questions the present study aims at answering. Section 3 presents an empirical analysis by describing the sample and the data under investigation. Section 4 discusses results in light of the managerial levels that companies have reached. Finally, limitations and avenues for further research are drawn in Section 5.

\section{Literature review and hypothesis development}

\subsection{The nexus between corporate governance and corporate social responsibility}

The concept of CG has its core essence in the "structure of rights and responsibilities among the parties with a stake in the firm" (Aoki, 2000, p. 11). The term has a proliferation of meanings coming from several viewpoints - ranging from the configuration of organizational processes to a broader concept that includes the "complex set of constraints that shape the ex post bargaining over the quasi-rents generated by the firm" (Rajan and Zingales, 1998). From this wider perspective, in other words, CG can be seen as the "set of relationships between a company's management, its board, its shareholders and other stakeholders" (OECD, 2015). Thus, CG mechanisms encompass rules, relationships, systems, and processes by which companies are held to account and in which compliance, 
accountability and transparency are leading peculiarities (Jamali, 2008). This means that CG drives "the tone for the organizations" (Jamali et al., 2008, p. 444) and "deals with the forces that influence how firms and their managers behave in the execution of their responsibilities" (Freeman et al., 2010, p. 110). A company's board of directors establishes proper decision-making processes to responsibly drive the company's activities. Hence, management's attention represents a peculiar element in defining the CG structure because its organizational attention defines the power of corporate strategic choices and decisions and plays a crucial role in driving CSR choices, as the behavioral theory of firms suggests (Cyert and March, 1963). Consequently, CG is strictly and tightly linked with how sustainable practices are conceived and then implemented within the business processes because the managerial attention can powerfully drive social and environmental issues (Jain and Jamali, 2016).

In this vein, the nexus between CG and CSR has attracted growing interest from scholars because of interlinked similarities, as for example the fiduciary and moral responsibilities of companies toward accountability. Jamali et al. (2008) identify three relational models deriving from previous studies: CG as a pillar of CSR $(\mathrm{Ho}, 2005), \mathrm{CSR}$ as a dimension of CG (Ho, 2005) and CG as a part of a continuum (Bhimani and Soonawalla, 2005). More specifically, CG can be viewed as an instrument for accomplishing sustainable CSR (Elkington, 2006); alternatively, CG can be addressed as the core of CSR enhancement because the more stewardship from directors and the more strategic processes are applied, the higher the level of CSR commitment achieved. Ultimately, CG and CSR are complementary because they can simultaneously focus on stakeholder value creation with an integrated framework as continuum (Bhimani and Soonawalla, 2005). They serve to delineate corporate accountability because, on the one hand, CG can lead to more attention to voluntary CSR performance, and on the other hand, CSR achieves social and environmental outcomes (Bhimani and Soonawalla, 2005).

As a consequence, three main streams of research should be acknowledged: the first considers CG as a driver for enhancing the CSR approach; the second views CSR as a method for CG; and the third addresses both CSR and CG as manifestations of firms' fiduciary and moral responsibilities to stakeholders (Aguilera et al., 2007; Jensen, 2002).

Considering the first stream of research, a prominent number of studies have addressed the role of CG in CSR by verifying the potential influences of the CG structure on environmental and social practices (Ducassy and Montandrau, 2015; Jo and Harjoto, 2012; Tuan, 2012). Among others, Jain and Jamali (2016) reviewed previous studies identifying that CG mechanisms (analyzed on four levels: institutional, firm, group and individual) shape CSR outcomes independently and interactively by demonstrating that CG is an antecedent of CSR. The authors invite reflection on the multiple configurations of CG mechanisms that forge and impact a firm's CSR behavior and explain how the different CG mechanisms are combined with each other to create CSR outcomes (Jain and Jamali, 2016).

Walls et al. (2012) provided a detailed literature review on the same stream of research to better understand the underlying theories, sets of variables and clarification of relationship findings among the variables. They then investigated how relationships between and among firm owners, managers and boards of directors affect environmental performance by highlighting, as a result, a positive and strong association. Recently, Hong et al. (2016) addressed how CG can explain the existence of incentives for CSR. They identify predictions on the link between CG and the existence of executive compensation incentives for CSR, demonstrating that CSR executive compensation constitutes an effective tool for CSR implementation.

Considering the second stream of research, CSR is viewed as a process rather than a "winning flag" through which firms legitimize their commitments. Thus, CSR represents a 
method for CG to prevent management control pitfalls (Jones, 1980) through which managers acknowledge fiduciary duties for both owners and stakeholders (Sacconi, 2006). Finally, the third stream of research aims at investigating the causality among CG mechanisms and CSR practices as well as the lag of both CSR and CG. For instance, a study conducted by Jo and Harjoto (2012) examined the association of CSR and CG, and it essentially discovered that the lag of CSR does not affect CG variables, whereas the lag of CG variables positively affect a firm's CSR engagement.

Grouping together all the aforementioned scholarly research, this study argues that CG mechanisms can enhance CSR practices when companies have to initially establish corporate policy in compliance with regulatory constraints. At a later stage, by embedding social and environmental practices in their core management processes, CSR can ameliorate CG mechanisms if it is conceived of as a process rather than a mere outcome. Based on this consideration, the present study formulates the following research hypotheses, which will be tested in the empirical analysis:

H1. CG mechanisms have a positive effect on CSR practices at a compliance level.

H2. CSR practices have a positive effect on CG mechanisms at a managerial level.

\subsection{The nexus between corporate social responsibility and financial performance}

Extensive research efforts have been devoted to addressing the relationship between CFP and CSR. Scholars have questioned whether CSR leads to increased results in CFP or if, on the contrary, whether CFP leads to better CSR (Waddock and Graves, 1997). Going further, some studies have provided outright meta-analyses to fill this gap (Friede et al., 2015; Margolis et al., 2009; Revelli and Viviani, 2015).

Several improvements have been developed in this regard. For instance, Reverte et al. (2016) consider corporate reputation, increased employee motivation and customer satisfaction as non-financial outcomes of CSR and goes on to examine the mediating effect of innovation in the explanation of a CSR-CFP relation. The literature acknowledges controversial and mixed results, and the debate is ongoing (Nollet et al., 2016).

Some previous research identifies CSR as having a positive association with CFP (Galbreath, 2006; Martínez-Ferrero and Frías-Aceituno, 2015; Reverte et al., 2016; Wang and Sarkis, 2017), whereas others show the opposite, highlighting a weak or insignificant relation among variables (Barnett and Salomon, 2012; Brammer and Pavelin, 2006; Mittal et al., 2008; Turban and Greening, 1997). The meta-analyses conducted by Friede et al. (2015), Margolis et al. (2009) and Revelli and Viviani (2015) support a positive relationship, suggesting that CSR generates high CFP and also that high CFP contributes to high levels of CSR. Hence, social issues are profitable, and CSR investments lead to improved financial returns, too. Among all of them, for instance, Nollet et al. (2016) precisely outline how linear specification models do not necessarily provide positive and significant results. Specifically, the authors demonstrate insignificancy between CSR and CFP with the linear model, while findings on quadratic models describe a significant U-shaped CSR-CFP relationship considering accounting-based measures (return on capital and return on assets). However, the U-shaped model is inconsistent with adopting financial-based measures such as excess stock market return; therefore, in the last case, the results suggest that CSR investments do not pay off immediately.

Such controversial results are due to different levels of stakeholder engagement within the decision-making process, leading to different ways that firms trade off financial, social and environmental choices (Barnett, 2007). Moreover, these misalignments may be attributed to a shortfall in the adoption of a rigorous method of analysis. For instance, some empirical studies in the past did not address the reverse causality problem, missed the consideration of moderating and mediating influences, or omitted significant latent variables, and 
consequently they provided deviating results (Margolis et al., 2009; Reverte, 2012; Reverte et al., 2016). Generally, academics employ empirical analysis in investing disparate sample groups that differ, for example, in terms of governance structure and company size, and thus, results reflect those different classifications. Moreover, various metrics of CFP have been taken into consideration and are divided into two main groups: accounting-based measures and market-based measures. Some studies have taken into consideration just accounting performance, such as return on assets, return on equity and return on capital, whereas others have considered financial market metrics like Tobin's $Q$ and excess stock market returns.

Recently, Chan et al. (2017); Rodriguez-Fernandez (2016) and Wang and Sarkis (2017) advanced debate on this stream of research. Starting from the assumption that performing CSR requires an injection of financial capital, Chan et al. (2017) investigated whether different states of cash flow liquidity impact the extent of CSR practices. The authors point out that firms in financial distress do not engage in any CSR activities, confirming a negative association between the level of CSR practices and the degree of financial constraints. Rodriguez-Fernandez (2016) and Wang and Sarkis (2017) addressed the mediating role of CG analyzing the Spanish context and the US one. Rodriguez-Fernandez (2016) considers the level of "compliance with the recommendations of Good Corporate Governance (a task of the board of directors)" (Rodriguez-Fernandez, 2016, p. 142) as a further element of CSR in disentangling the CSR-CFP relation. The study discovered that social policies increment financial resources, and vice versa, increased CFP leads to greater social benefits in the Spanish case.

Finally, Wang and Sarkis (2017) based their study on the assumption that CSR performance mediates the relationship between CSR governance and CFP, and they essentially pointed out that "companies will benefit from implementing CSR governance only when they can 'walk the talk' by seriously implementing CSR governance to achieve superior CSR outcomes" (p. 1615).

As a consequence, with regard to the relationship between CSR and CFP, the following subsequent hypotheses will be addressed in this study:

H3. CFP practices have a positive and significant effect on CSR at a compliance level.

H4. CSR practices have a positive and significant effect on CFP at a managerial level.

With these concepts in mind, the present research addresses both CG and CFP as positive and significant factors that may stimulate higher levels of environmental and social practices and, conversely, these sustainable actions may be profitable and enhance the whole organization in a virtuous cycle (Figure 1).

Accordingly, Section 3 presents the research methodology of the study upon which the empirical findings are based.

Figure 1 The nexus between CG-CFP-CSR

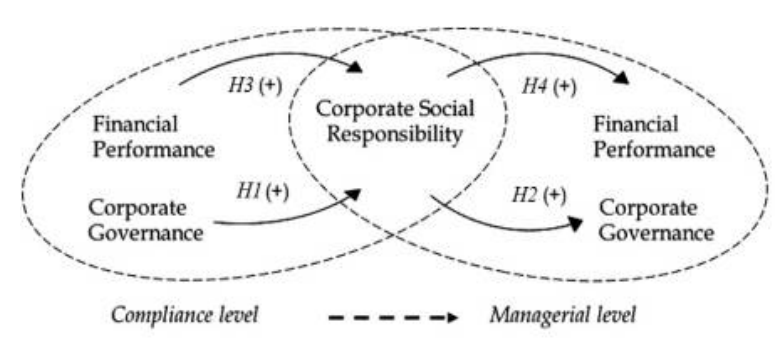




\section{Methodology}

\subsection{Data}

All data were obtained from the DataStream database owned by Thomson Reuters. DataStream provides a company's ESG commitment across three dimensions: environmental performance (emissions reduction, resource reduction and product innovation), social performance (employment quality, health and safety, training and development, diversity, human rights, community and product responsibility) and CG structure (management).

The initial sample took into account 459 non-financial listed companies in Europe from France, Germany, Italy, Spain, and the UK. Data were filtered by excluding banking, insurance, and real estate firms because of differences in accounting systems and in financial ratios that could lead to inhomogeneity in the comparison of results. Next, data available for those companies that provide ESG indicators were taken into account. Specifically, companies without a full ESG disclosure were excluded from the sample under investigation, so this work could guide companies that are not CSR-oriented enough in the practical implementation of ESG disclosure. Thus, after deleting missing data and outliers at the 0.01 and 0.99 percentiles, the final dataset examined 361 listed companies with a crosssectional analysis over one year of observations for 2016.

The assessment of companies' exposure to and management of CSR practices is displayed by DataStream's environmental and social scores, which are based on company reported data such as annual reports, CSR reports, stock exchange filings and company websites and news sources.

For measuring the level of social outcomes, DataStream provides social performance scores. The present analysis included the social performance scores for workforce protection, product responsibility, human rights and community enhancement, which are at the core of social business practices. The workforce quality category measures a company's commitment at providing employment benefits and job conditions and at increasing the loyalty of its workforce. Product responsibility measures a company's effectiveness in creating value-added products, quality goods and services upholding the customer's security and health. The human rights category refers to a company's principles in respecting fundamental human rights by guaranteeing the freedom of association and labor. Finally, community enhancement is the objective to operate sustainably within the community where the company is based.

For measuring the levels of environmental practices, the dataset includes resource use, emissions reduction and levels of environmental innovation performed by companies. The resource reduction category assesses the capability to achieve an efficient use of natural resources, thus high resource reduction scores demonstrate how a company improves the supply chain process toward the reduction of use of materials, energy or water and increasing the use of eco-efficient solutions. The emissions reduction score rates a company's level of environmental emissions reduction in terms of its production and operational processes. Finally, the product innovation category takes into account the development of eco-efficient products or services with the aim of reducing environmental costs and extending durability.

For the explanation of CG mechanisms, the management score and the vision and strategy score assess the capability of the firm to apply best management practices to direct its rights and responsibilities and generate long-term value.

Next, we included Tobin's $Q$ for the measurement of CFP, in accordance with previous studies (Rodriguez-Fernandez, 2016; Wang and Sarkis, 2017). Tobin's Q is a market value metric that measures how the market values a firm's operating efficiency and ability to generate good CFP (Tobin, 1969). It is calculated by the market value of the company's stock divided by its book value (Perfect and Wiles, 1994). 
Along with the core variables of interest in this study (environmental and social practices, CG mechanisms and CFP), the following control variables were considered: leverage ratio (which serves as a proxy for risk), total revenues, total assets, beta, liquidity and Z-score. The choice of these variables can be justified by recent studies which find firm size and risk (as measured by the ratio of total debt to total assets) essential components for the investigation the effects of CSR on CFP (McWilliams and Siegel, 2000; Zellweger and Sieger, 2012). We also included each country's credit rating, which generally controls trends at a macroeconomic level and dummies for each sector to set differences. A final category under consideration, shareholders' rights, represents the commitment to addressing shareholder policy to ensure equal treatment of shareholders by, for instance, limiting the use of anti-takeover operations.

\subsection{Method of estimation}

Following the variable specifications, a multivariate linear regression analysis on a sample of 361 non-financial listed companies was carried out: three models were addressed. Model 1 aimed at testing $\mathrm{H}_{1}$ and $\mathrm{H} 3$, and thus considered the CSR score (grouping social and environmental practices together) as the dependent variable and the governance score (considering the management score, vision, and strategy) and Tobin's $Q$ (for explanation of the CFP) as the independent variables. Model 2 aimed at verifying $\mathrm{H}_{2}$, and thus acknowledged the governance score as the dependent variable and the CSR score as the independent variable. Finally, Model 3 aimed at verifying $H 4$, and hence, Tobin's Q is the dependent variable and the CSR score is the independent variable. The linear regression models used the following equations:

$$
\begin{aligned}
& \text { CSR_Score }_{i t}=\beta_{0}+\beta_{1} \text { Governance_Score }_{i t}+\beta_{2} \text { TOBINQ }_{i t}+\beta_{3} \text { Shareholders }_{i t} \\
& +\beta_{4} \text { controls_variables it }+\varepsilon \\
& \text { Governance_Score }_{i t}=\beta_{0}+\beta_{1} \text { CSR_Score }_{i t}+\beta_{2} \text { TOBINQ }_{i t}+\beta_{3} \text { Shareholders }_{\text {it }} \\
& +\beta_{4} \text { controls_variables it }+\varepsilon \\
& \text { TOBINQ }{ }_{i t}=\beta_{0}+\beta_{1} \text { CSR_Score }_{i t}+\beta_{2} \text { Governance_Score }_{i t}+\beta_{3} \text { Shareholders }_{i t} \\
& +\beta_{4} \text { controls_variablesit }+\varepsilon
\end{aligned}
$$

where $i$ and $t$ indicates each company observations $(i)$ for the year $2016(t)$. The control variables were listed as follows: Leverage, Liquidity, Ln_Total_Asset, Ln_Total_Revenue, Zscore, Beta, dummy_sectors (eight variables), and dummy_rating (two variables).

\section{Results}

Results are clustered into the subsequent analysis. The sample under analysis illustrates the comparison of data among social and environmental practices as well as the CG structure for each country; in order to outline similarities and differences among countries, the initial sample of 459 companies is presented. Descriptive statistics and a pairwise correlation matrix show, respectively, summarized data and the correlation coefficient for each variable taken into consideration. Then, the study presents findings deriving from the multivariate regression analysis, though which the hypotheses were tested.

\subsection{Descriptive analysis}

The study identified two main peculiarities that essentially depend on the country where a company has enhanced CSR practices, and on the level of CSR that companies have 
achieved. Table I displays the initial sample of 359 non-financial listed companies from France, Germany, Italy, Spain and the UK. For each country, the frequencies of the CSR score, social score, environmental score and CG score have been presented.

Concerning the country of headquarters, the results show that the UK is the foremost one applying social and environmental practices, accounting for 54.30 per cent of the total sample of companies under analysis. The other countries - France, Germany and Spain provided much more homogenous results and, respectively, counted for 16.99, 15.67 and 7.72 per cent of the sample under analysis. Finally, the Italian listed companies do not disclose social and environmental practices in enough detail, and only 24 listed companies provided any such information.

With regard to the level of ESG performance achieved, the analysis shows that the level of social commitment is classified between 50 and 75 for 41.61 per cent of the companies under analysis. Similarly, 44.22 per cent of companies achieved environmental performance scores that ranged from 50 to 75 . This means that half of the companies that disclosed their social and environmental practices are deeply committed. Lower results are achieved for the disclosure and implementation of CG mechanisms. As a matter of fact, 49.45 per cent of the companies achieved a governance score lower than 50 points.

This evidence is also confirmed by the descriptive statistics of the variables under consideration. Whereas the mean of environmental score and social score sets at 65.05 and 64.02, respectively, the governance score is lower, at 52.01. Going in-depth into the analysis of CFP, Tobin's Q, liquidity and the Z-score show good financial results, in mean. Finally, beta describes the general attitude of the companies in taking risks, and it is 0.88 in mean. Table II illustrates the descriptive results.

Table I Comparison among countries

\begin{tabular}{|c|c|c|c|c|c|c|}
\hline \multirow[b]{2}{*}{ Variables } & \multicolumn{5}{|c|}{ Country of headquarters } & \multirow[b]{2}{*}{ Tota } \\
\hline & France & Germany & Italy & Spain & The UK & \\
\hline \multicolumn{7}{|c|}{ CSR_Score } \\
\hline $0-25$ & 0 & 3 & 2 & 1 & 13 & 13 \\
\hline $25-50$ & 8 & 14 & 5 & 6 & 105 & 138 \\
\hline $50-75$ & 44 & 31 & 11 & 15 & 112 & 213 \\
\hline $75-100$ & 25 & 23 & 6 & 13 & 22 & 89 \\
\hline Total & 77 & 71 & 24 & 35 & 246 & 453 \\
\hline \multicolumn{7}{|c|}{ Social_Score } \\
\hline $0-25$ & 0 & 3 & 1 & 1 & 9 & 11 \\
\hline $25-50$ & 13 & 11 & 4 & 3 & 72 & 91 \\
\hline $50-75$ & 27 & 25 & 8 & 12 & 119 & 203 \\
\hline $75-100$ & 38 & 34 & 11 & 19 & 49 & 154 \\
\hline Total & 78 & 73 & 24 & 35 & 249 & 459 \\
\hline \multicolumn{7}{|l|}{ Env_Score } \\
\hline $0-25$ & 0 & 2 & 2 & 0 & 7 & 11 \\
\hline $25-50$ & 2 & 11 & 5 & 5 & 68 & 91 \\
\hline $50-75$ & 26 & 33 & 5 & 17 & 122 & 203 \\
\hline $75-100$ & 50 & 27 & 12 & 13 & 52 & 154 \\
\hline TOTAL & 78 & 73 & 24 & 35 & 249 & 459 \\
\hline \multicolumn{7}{|c|}{ Governance_Score } \\
\hline $0-25$ & 17 & 14 & 0 & 10 & 36 & 77 \\
\hline $25-50$ & 21 & 16 & 1 & 10 & 58 & 106 \\
\hline $50-75$ & 21 & 15 & 0 & 10 & 43 & 165 \\
\hline $75-100$ & 19 & 19 & 0 & 5 & 55 & 98 \\
\hline Total & 78 & 64 & 1 & 35 & 192 & 370 \\
\hline
\end{tabular}




\begin{tabular}{lcccc}
\multicolumn{4}{l}{ Table II Descriptive statistics } \\
Variable & Mean & SD & Min & Max \\
\hline CSR_Score & 58.44821 & 16.86935 & 7.467533 & 90.71949 \\
Env_Score & 65.05129 & 19.46537 & 8.072917 & 99.00497 \\
Social_Score & 65.02493 & 19.56420 & 8.761683 & 98.53395 \\
Governance_Score & 52.01097 & 28.20810 & 0.3826531 & 99.61538 \\
TobinQ & 1.270960 & 1.152722 & 0.0913762 & 6.812991 \\
Shareholders_Score & 52.18472 & 29.13675 & 0.1196172 & 99.61735 \\
Leverage & 0.9744991 & 1.948773 & -13.48531 & 16.71708 \\
Liquidity & 1.613022 & 2.289724 & 0.0499445 & 46.81448 \\
Ln_total_asset & 22.31462 & 1.595505 & 18.47373 & 26.73877 \\
Ln_total_revenue & 21.89216 & 1.655646 & 11.80428 & 26.10439 \\
ZScore & 3.300791 & 6.381895 & -3.782858 & 5.5972 \\
Beta & 0.8671068 & 0.4486182 & -0.5937140 & 3.486364
\end{tabular}

Correlations among variables are exhibited in Table III, which demonstrates that to some extent, the variables are correlated with each other. In addition to the above, a multicollinearity check among variables was employed by using the variance inflation factor (VIF) test. Correlation results do not show VIF higher than 0.70 among dependent and independent variables, with one exception, being between the Z-score and liquidity $\left(0.905^{\star * *}\right)$. However, these correlations affect our control variables, which is intuitively reasonable because the $Z$-score implies liquidity ratio in its formula.

The correlation between total revenue and CSR score $\left(0.612^{\star \star *}\right)$ and the correlation between CSR score and total assets $\left(0.603^{\star \star \star}\right)$ were close to the threshold. This is also acceptable because total assets and total revenues imply a correlation with the firm size. Thus, multicollinearity has not compromised our empirical results.

\subsection{Regression analysis}

Results of the regression analysis are illustrated in Tables IV and V, which show the beta coefficient and the robust standard errors in parentheses of each variable under investigation. In particular, Table IV describes the effect of CG and CFP on social and environmental outcomes. Model 1 sought to verify if the governance score and CFP impact the CSR score. It was shown that each increase of one unit of the governance score led to CSR score increases of 0.0757 , as confirmed by the positive and significant coefficient (beta $=0.0757, p<0.01$ ). Similarly, the regression provides strong results for CFP. The positive and significant coefficient (beta $=2.651, p<0.01$ ) expresses that an increase of one unit of CFP leads to levels of social and environmental performance increasing by

\section{Table III Correlation among variables}

Variables (1) (2)

(2) (3)

(4)

(5)

(6)

(7)

(8)

(9)

(10)

\begin{tabular}{|c|c|c|c|c|c|c|c|c|c|c|}
\hline (1) CSR_Score & 1.000 & & & & & & & & & \\
\hline (2) Governance_Score & $0.234^{\star * \star}$ & 1.000 & & & & & & & & \\
\hline (3) TobinQ & $0.121^{\star}$ & -0.0536 & 1.000 & & & & & & & \\
\hline (4) Leverage & 0.0740 & -0.0721 & $-0.208^{\star \star \star}$ & 1.0000 & & & & & & \\
\hline (5) Liquidity & $-0.206^{\star * *}$ & -0.0972 & $0.121^{\star}$ & -0.0787 & 1.0000 & & & & & \\
\hline (6) Ln_total_asset & $0.603^{\star \star \star}$ & $0.181^{\star \star \star}$ & $-0.380^{\star \star \star}$ & $0.176^{\star \star \star}$ & $-0.237^{\star \star \star}$ & 1.0000 & & & & \\
\hline (7) Ln_total_revenue & $0.612^{\star \star \star}$ & $0.184^{\star \star \star}$ & $-0.278^{\star \star \star}$ & $0.160^{* *}$ & $-0.454^{\star \star \star}$ & $0.850^{\star * *}$ & 1.000 & & & \\
\hline (8) Shareholder_Score & 0.0651 & $0.145^{\star \star}$ & 0.0198 & 0.0163 & -0.0625 & -0.0273 & 0.0175 & 1.0000 & & \\
\hline (9) Z-Score & $-0.220^{\star \star \star}$ & -0.0913 & $0.337^{\star \star *}$ & $-0.124^{\star}$ & $0.905^{\star \star \star}$ & $-0.267^{\star \star \star}$ & $-0.432^{\star * \star}$ & -0.0879 & 1.0000 & \\
\hline (10) Beta & $0.123^{*}$ & $0.127^{\star}$ & $-0.190^{\star \star *}$ & -0.0299 & -0.0893 & $0.215^{\star \star *}$ & $0.141^{* \star}$ & 0.0421 & $-0.151^{\star *}$ & 1.0000 \\
\hline
\end{tabular}

Notes: ${ }^{* *} p<0.01 ;{ }^{* *} p<0.05 ;{ }^{*} p<0.1$ 
Table IV OLS multiple regression - CSR as dependent variable

(1)

(2)

(3)

\begin{tabular}{|c|c|}
\hline Variables & CSR_Score \\
\hline Governance_Score & 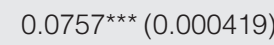 \\
\hline TobinQ & $2.651^{\star \star \star}(0.002000)$ \\
\hline Shareholder_Score & $0.000272(0.989)$ \\
\hline Leverage & $0.0764(0.792)$ \\
\hline Liquidity & $1.679^{\star \star \star}(0.00419)$ \\
\hline Ln_total_asset & $1.709^{\star \star \star}(0.0412)$ \\
\hline Ln_total_revenue & $2.828^{* * *}(0.000223)$ \\
\hline Z-Score & $-0.735^{\star \star *}(0.00134)$ \\
\hline Beta & $-0.0286(0.986)$ \\
\hline Constant & $-37.80^{\star * *}(0.00145)$ \\
\hline Observations & 361 \\
\hline$R^{2}$ & 0.552 \\
\hline
\end{tabular}

Social_Score

Env_Score

Notes: Robust standard errors in parentheses; ${ }^{* * *} p<0.01,{ }^{* *} p<0.05,{ }^{*} p<0.1$

\section{Table V OLS multiple regression - CSR as independent variable}

(4)

\begin{tabular}{lc} 
Variables & Tobin's $Q$ \\
\hline CSR_Score & $0.0186^{\star \star *}(6.95 \mathrm{e}-05)$ \\
Governance_Score & $-0.00229(0.237)$ \\
TobinQ & \\
Shareholder_Score & $0.000258(0.113)$ \\
Leverage & $-0.0167(0.481)$ \\
Liquidity & $-0.420^{\star * *}(3.35 \mathrm{e}-05)$ \\
Ln_total_asset & $-0.362^{\star * *}(0.000357)$ \\
Ln_total_revenue & $0.0615(0.537)$ \\
Z-Score & $-0.183^{\star * *}(1.83 \mathrm{e}-06)$ \\
Beta & $0.00589(0.957)$ \\
Constant & $6.249^{\star * *}(6.07 \mathrm{e}-10)$ \\
Observations & 361 \\
$R^{2}$ & 0.516
\end{tabular}

(5)

Governance Score
$0.0437(0.141)$

$2.173^{\star \star *}(0.00764)$

$0.000846(0.753)$

$0.211(0.646)$

$0.987(0.197)$

$-0.159(0.987)$

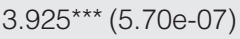

$-0.435(0.149)$

$-0.187(0.935)$

$-26.46^{*}(0.0845)$

364

0.429

Notes: Robust standard errors in parentheses; ${ }^{\star \star *} p<0.01$; ${ }^{* *} p<0.05 ;{ }^{*} p<0.1$

2.651. Therefore, this study confirms $\mathrm{H} 2$ in line with previous studies (Rodriguez-Fernandez, 2016; Wang and Sarkis, 2017).

To understand which sphere of social and environmental practices is driving such relations, the study splits the multivariate regression analysis into two models. Models 2 and 3 present findings for the environmental performance and the social performance, respectively. Results confirm that Tobin's $Q$ is significant, at a level of 99 per cent, and it affects social and environmental practices positively and significantly: beta coefficient sets at 2.849 ( $p<$ $0.01)$ for social performance and at $2.173(p<0.01)$ for environmental performance. That means an increase of one unit of the governance score leads to the social performance score increasing 2.849 and the environmental performance score increasing 2.173. With regard to the role of $C G$, the impact is significant: social performance increases 0.107 with each increase of one unit in the governance score. However, the results do not provide consistent evidence concerning the effect of the governance score on higher levels of environmental performance, and consequently, the findings indicate that the governance structure has a higher level of attention toward social practices than environmental ones.

Table $V$ shows the empirical evidence concerning the effect of CSR practices on both Tobin's Q (Model 4) and governance score (Model 5). The positive effect of the CSR score on the governance score was confirmed by the beta coefficient (0.469); an increase of one 
unit of the CSR score leads to an increase of 0.469 in the governance score $(p<0.01)$. Similarly, an increase of one unit of the CSR score leads to CFP increases of 0.0186 (Model 5). Consequently, both $\mathrm{H} 2$ and $\mathrm{H} 4$ are confirmed.

Taking a look at our control variables, the study acknowledges total assets and liquidity are positively associated with the CSR score; the beta coefficients are, respectively, 1.679 ( $p<$ $0.01)$ and $1.709(p<0.05)$. Finally, the $Z$-score confirms that an increase of one unit in the level of bankruptcy probability leads to a decrease in social performance of 0.735 in Model 1 and 1.252 in Model 2, with a significance of 99 per cent ( $p$-value $<0.01$ ).

All things considered, the study shows empirical evidence of positive effects of a CG structure and CFP in forging social and environmental practices by leading to higher levels of CSR outcomes. Hence, $\mathrm{H} 1$ and $\mathrm{H} 3$ are confirmed. Furthermore, the findings describe the capacity of CSR to influence both the CG structure and the CFP, therefore confirming both $\mathrm{H} 2$ and $\mathrm{H} 4$.

\section{Discussion, limitations and avenues for further research}

This research attempts to reconcile the conflicting understanding of the nexus between CG, CFP, and CSR in the context of five countries in Europe. It proposes a comprehensive framework of those relationships to address how companies engage with sustainable practices and deliver sustainability programs by considering which role the CG structure and the CFP each play.

Two main empirical findings resulted: first, the CG structure and CFP are both meaningful for CSR performance given that they affect social and environmental practices strongly and significantly. Both the CG score and the Tobin's $Q$ appear to be positive and significant. Second, the CSR approach can drive CG mechanisms and simultaneously enhance CFP if managers perceive the implementation of sustainable practices as a process rather than an outcome. Thereby, CSR impacts on both CG and CFP. These results are in line with Jo and Harjoto (2012), Rodriguez-Fernandez (2016) and Wang and Sarkis (2017).

As a matter of fact, prior scholarly works have treated CSR as a missing link between CG and CFP, providing the positive effect of CSR on CFP (Jo and Harjoto, 2012); likewise, Rodriguez-Fernandez (2016) suggests that boards of directors can guide shareholders and investors regarding CSR investment decision-making.

With the attempt to contribute to such debate, this research acknowledges the following theoretical and managerial implications.

From a theoretical viewpoint, the study confirms the insights of Elkington (2006) and Jamali et al. (2008) suggesting an extremely meaningful role of CG in addressing CSR practices. At the compliance level, by applying mandatory disclosure, CG can forge corporate social legitimacy, and adequate CFP leads to higher levels of socially and environmentally sustainable outcomes. Thus, the objective is to pursue "economically necessary and socially desirable functions" (Arthur, 1987). On a managerial level, when CSR activities are part of daily operations processes, this study points to ameliorating effects of CSR on both the CG structure and the CFP. Hence, the virtuous cycle between CG-CFP-CSR seems to be appropriate.

From a managerial viewpoint, the study acknowledges differences in the application of social and environmental disclosure between countries. First, the research demonstrates that managerial attention is more focused on the sphere of social practices than on environmental practices and this strongly impacts the level of social performance achieved by companies. Second, the research presents heterogeneous results concerning the level of CSR disclosure among those five European countries. In particular, the descriptive statistics show disparate levels of environmental and social commitment among countries. Therefore, the intent of this study is to provide suggestions to managers in those countries where CSR practices are 
lacking. There are several positive effects for companies that disclose social and environmental practices, including the information asymmetry and the reduction in costs from adverse selection, as well as the enhanced reputation and better risk estimation, resulting in the reduction of stock volatility (García-Sánchez and Noguera-Gámez, 2017). Moreover, the combination of both financial and non-financial factors leads to higher levels of accuracy in default probability estimation (Grunert et al., 2005; Weber et al., 2010).

The results of the present study are subject to several limitations, which could lead to further research, both theoretical and empirical. First, the study does not shed light on a clear distinction between "greenwashing" companies that engage in CSR activities as an opportunistic behavior while trying to improve the corporate image and those companies that implement CSR governance for the broader societal benefit (Kim et al., 2012). Therefore, further research could investigate the corporate responsibility path (Zadek, 2004) as the learning process through which companies approach CSR practices, with the full integration of CSR practices into their business models and strategic decision-making processes. Second, the present research limits the analysis to the social and environmental performance of companies that communicate their commitment to society. In other words, it addresses CSR practices at the compliance and managerial level of CSR implementation within business activities without taking into account relations among stakeholders. If CSR is considered as an approach that "takes account for" the interest of stakeholders (Jamali, 2008), it might therefore be argued that taking CSR, CG and CFP independently and understanding the effect of each variable on the others can expose just a partial effect of how companies, along with stakeholders, effectively contribute to the value creation. Similarly, as suggested by de Colle et al. (2014), inertly following of the international standards (e.g. the GRI standards) by just ticking a box might support the "thoughtless, blind and blinkered mindset of the CSR paradox," as CSR measures and ESG performance can be "measures of the unmeasurable" (de Colle et al., 2014, p. 184).

In line with Haslam et al. (2015), we argue that the existing research is lacking in the disclosure of stakeholder relationship information, and academics can develop this stream of research. To fully pursue a sustainable approach, which looks to the achievement of long-term competitive advantages with a cooperative strategy among stakeholders, it is likely to become increasingly necessary to move from the compliance approach to a strategic management approach. For such reasons, strategic decisions of resource allocations should go beyond the instrumental standalone approach in favor of the value creation of all stakeholders, meaning consideration of how stakeholder groups and companies interact with each other and how they align their interests. Therefore, further research could try to understand how companies strategically integrate social and environmental commitments in their core strategic decisions with the identification of stakeholder interests.

\section{References}

Aguilera, R.V., Rupp, D.E., Williams, C.A. and Ganapathi, J. (2007), "Putting the S back in corporate social responsibility: a multilevel theory of social change in organizations", Academv of Management Review, Vol. 32 No. 3, pp. 836-863.

Aguilera, R.V., Williams, C.A., Conley, J.M. and Rupp, D.E. (2006), "Corporate governance and social responsibility: a comparative analysis of the UK and the US", Corporate Governance: An International Review, Vol. 14 No. 3, pp. 147-158.

Aoki, M. (2000), Information, Corporate Governance, and Institutional Diversity: Competitiveness in Japan, the USA, and the Transitional Economies, Oxford University Press, Oxford.

Arthur, E.E. (1987), "The ethics of corporate governance", Journal of Business Ethics, Vol. 6 No. 1, pp. 59-70.

Barnett, M.L. (2007), "Stakeholder influence capacity and the variability of financial returns to corporate social responsibility", Academy of Management Review, Vol. 32 No. 3, pp. 794-816. 
Barnett, M. and Salomon, R. (2012), "Does it pay to be really good? addressing the shape of the relationship between social and financial performance", Strategic Management Journal, Vol. 33 No. 11, pp. 1304-1320, doi: 10.1002/smj.

Bhimani, A. and Soonawalla, K. (2005), "From conformance to performance: the corporate responsibilities continuum", Journal of Accounting and Public Policy, Vol. 24 No. 3, pp. 165-174.

Brammer, S. and Pavelin, S. (2006), "Voluntary environmental disclosures by large UK companies", Journal of Business Finance \& Accounting, Vol. 33 Nos 7/8, pp. 1168-1188, doi: 10.1111/j.14685957.2006.00598.x

Chan, C.Y., Chou, D.W. and Lo, H.C. (2017), "Do financial constraints matter when firms engage in CSR?", North American Journal of Economics and Finance, Vol. 39, pp. 241-259, doi: 10.1016/j. najef.2016.10.009.

Croker, N.C. and Barnes, L.R. (2017), "Epistemological development of corporate social responsibility: the evolution continues", Social Responsibility Journal, Vol. 13 No. 2, pp. 279-291, doi: 10.1108/SRJ-022016-0029.

Cullinan, C.P., Mahoney, L.S. and Roush, P. (2016), "Corporate social responsibility and shareholder support for corporate governance changes", Social Responsibility Journal, Vol. 12 No. 4, pp. 687-705, doi: 10.1108/SRJ-10-2015-0161.

Cyert, R.M. and March, J.G. (1963), A Behavioral Theory of the Firm, Blackwell Publishers, Englewood Cliffs, NJ, p. 2

de Colle, S., Henriques, A. and Sarasvathy, S. (2014), "The paradox of corporate social responsibility standards", Journal of Business Ethics, Vol. 125 No. 2, pp. 177-191.

Ducassy, I. and Montandrau, S. (2015), "Corporate social performance, ownership structure, and corporate governance in France", Research in International Business and Finance, Vol. 34, pp. 383-396, doi: 10.1016/j.ribaf.2015.02.002.

Elkington, J. (2006), "Governance for sustainability", Corporate Governance. An International Review, Vol. 14 No. 6, pp. 522-529.

European Commission (2011), Communication from the Commission to the European Parliament, the Council, the European Economic and Social Committee and the Committee of the Regions. A Renewed EU Strategy 2011-14 for Corporate Social Responsibility, European Commission, available at: www. europarl.europa.eu/meetdocs/2009_2014/documents/com/com_com(2011)0681_com_com(2011)0681_en. pdf

Freeman, R.E., Harrison, J.S., Wicks, A.C., Parmar, B.L. and de Colle, S. (2010), Stakeholder Theory. The State of the Art, Cambridge University Press, Cambridge, MA.

Friede, G., Busch, T. and Bassen, A. (2015), "ESG and financial performance: aggregated evidence from more than 2000 empirical studies", Journal of Sustainable Finance \& Investment, Vol. 5 No. 4, pp. 210-233, doi: 10.1080/20430795.2015.1118917.

Galbreath, J. (2006), "Does primary stakeholder management positively affect the bottom line? Some evidence from Australia", Management Decision, Vol. 44 No. 8, pp. 1106-1121.

García-Sánchez, I.M. and Noguera-Gámez, L. (2017), "Integrated reporting and stakeholder engagement: the effect on information asymmetry", Corporate Social Responsibility and Environmental Management, Vol. 24 No. 5, pp. 395-413, doi: 10.1002/csr.1415.

Grunert, J., Norden, L. and Weber, M. (2005), "The role of non-financial factors in internal credit ratings", Journal of Banking \& Finance, Vol. 29 No. 2, pp. 509-531, doi: 10.1016/j.jbankfin.2004.05.017.

Haslam, C., Tsitsianis, N., Andersson, T. and Gleadle, P. (2015), "Accounting for business models: increasing the visibility of stakeholders", Journal of Business Models, Vol. 3 No. 1, pp. 62-80.

Ho, C.K. (2005), "Corporate governance and corporate competitiveness: an international analysis", Corporate Governance. An International Review, Vol. 13 No. 2, pp. 211-253.

Hong, B., Li, Z. and Minor, D. (2016), "Corporate governance and executive compensation for corporate social responsibility", Journal of Business Ethics, Vol. 136 No. 1, pp. 199-213, doi: 10.1007/s10551-0152962-0.

Jain, T. and Jamali, D. (2016), "Looking inside the black box: the effect of corporate governance on corporate social responsibility", Corporate Governance, An International Review, Vol. 24 No. 3, pp. 253-273, doi: 10.1111/corg. 12154. 
Jamali, D. (2008), "A stakeholder approach to corporate social responsibility: a fresh perspective into theory and practice", Journal of Business Ethics, Vol. 82 No. 1, pp. 213-231.

Jamali, D., Safieddine, A.M. and Rabbath, M. (2008), "Corporate governance and corporate social responsibility synergies and interrelationships", Corporate Governance. An International Review, Vol. 16 No. 5, pp. 443-459.

Jensen, M.C. (2002), "Value maximization, stakeholder theory, and the corporate objective function", Business Ethics Quarterly, Vol. 12 No. 2, pp. 235-256.

Jo, H. and Harjoto, M.A. (2012), "The causal effect of corporate governance on corporate social responsibility", Journal of Business Ethics, Vol. 106 No. 1, pp. 53-72, doi: 10.1007/s10551-011-1052-1.

Jones, T.M. (1980), "Corporate social responsibility revisited, redefined”, California Management Review, Vol. 22 No. 3, pp. 59-67.

Kim, Y., Park, M.S. and Wier, B. (2012), "Is earnings quality associated with corporate social responsibility?", The Accounting Review, Vol. 87 No. 3, pp. 761-796.

McWilliams, A. and Siegel, D. (2000), "Corporate social responsibility and financial performance: correlation or misspecification”, Strategic Management Journal, Vol. 21 No. 5, pp. 603-609.

Margolis, J.D. Elfenbein, H.A. Walsh, J.P. (2009), "Does it pay to be good. . . and does it matter? A metaanalysis of the relationship between corporate social and financial performance", available at: https:// ssrn.com/abstract $=1866371$

Martínez-Ferrero, J. and Frías-Aceituno, J.V. (2015), "Relationship between sustainable development and financial performance: international empirical research", Business Strategv and the Environment, Vol. 24 No. 1, pp. 20-39, doi: 10.1002/bse.1803.

Mittal, R.K., Sinha, N. and Singh, A. (2008), "An analysis of linkage between economic value added and corporate social responsibility”, Management Decision, Vol. 46 No. 9, pp. 1437-1443, doi: 10.1108/ 00251740810912037.

Nidumolu, R., Simmons, P.J. and Yosie, T.F. (2015), "Sustainability and the CFO: challenges, opportunities and next practices", paper presented at Corporate EcoForum, World Environment Center, available at: $w w w . g o o g l e . c o m / u r l$ sa $=t \& r c t=j \& q=\& e s r c=s \&$ source=web\& $c d=1 \& c a d=r j a \& u a c t=8 \&$ ved $=$ OahUKEwi1hvLqp9TZAhVBSWMKHQyQDVYQFggpMAA\&url=http\%3A\%2F\%2Fwww.corporateecoforum. com\%2Fwp-content\%2Fuploads\%2F2015\%2F04\%2FCFO_and_Sustainability_Apr-2015.pdf\&usg=AOvVaw 3WzgjoQBZrRY8bVbk8nvx

Nollet, J., Filis, G. and Mitrokostas, E. (2016), "Corporate social responsibility and financial performance: a non-linear and disaggregated approach", Economic Modelling, Vol. 52, pp. 400-407, doi: 10.1016/j. econmod.2015.09.019.

OECD (2015), "G20/OECD principles of corporate governance", available at: www.oecd.org/daf/ca/ Corporate-Governance-Principles-ENG.pdf?TSPD_101_R0=f5e12ac480cae9c44032b972f331f7bdjU50 $00000000000000003 e 46 f c 7 f f f 00000000000000000000000000005 a 9 d 511500 c 926573 f$

Perfect, S.B. and Wiles, K.W. (1994), "Alternative constructions of Tobin's q: an empirical comparison", Journal of Empirical Finance, Vol. 1 Nos 3/4, pp. 313-341.

Perrini, F., Russo, A., Tencati, A. and Vurro, C. (2012), "Deconstructing the relationship between corporate social and financial performance", Journal of Business Ethics, Vol. 102 No. S1, pp. 59-76, doi: 10.1007/s10551-011-1194-1.

Rajan, R.G. and Zingales, L. (1998), "Power in a theory of the firm", Quarterly Journal of Economics, Vol. 113 No. 2, pp. 387-432.

Revelli, C. and Viviani, J.-L. (2015), "Financial performance of socially responsible investing (SRI): what have we learned? A meta-analysis", Business Ethics, A European Review, Vol. 24 No. 2, pp. 158-185, doi: 10.1111/beer.12076.

Reverte, C. (2012), "The impact of better corporate social responsibility disclosure on the cost of equity Capital”, Corporate Social Responsibility and Environmental Management, Vol. 19 No. 5, pp. 253-272, doi: $10.1002 /$ csr.273.

Reverte, C., Gómez-Melero, E. and Cegarra-Navarro, J.G. (2016), "The influence of corporate social responsibility practices on organizational performance: evidence from eco-responsible spanish firms", Journal of Cleaner Production, Vol. 112 No. 4, pp. 2870-2884.

Rezaee, Z. (2017), "Corporate sustainability: theoretical and integrated strategic imperative and pragmatic approach", Journal of Business Inquiry: Research, Education \& Application, Vol. 16 No. 1, pp. 60-87. 
Rodriguez-Fernandez, M. (2016), "Social responsibility and financial performance: the role of good corporate governance", BRQ: Business Research Quarterly, Vol. 19 No. 2, pp. 137-151, doi: 10.1016/j. brq.2015.08.001.

Sacconi, L. (2006), "A social contract account for CSR as an extended model of corporate governance (I): rational bargaining and justification”, Journal of Business Ethics, Vol. 68 No. 3, pp. 259-281.

Surroca, J., Tribó, J.A. and Waddock, S. (2010), "Corporate responsibility and financial performance: the role of intangible resources", Strategic Management Journal, Vol. 31 No. 5, pp. 463-490.

Tobin, J. (1969), "A general equilibrium approach to monetary theory", Journal of Monev. Credit and Banking, Vol. 1 No. 1, pp. 15-29.

Tonello, M. and Singer, T. (2015), "The business case for corporate investment in ESG practices", The Conference Board, available at: www.conference-board.org/publications/publicationdetail.cfm? publicationid $=2996$

Tuan, L.T. (2012), "Corporate social responsibility, ethics, and corporate governance", Social Responsibility Journal, Vol. 8 No. 4, pp. 547-560, doi: 10.1108/17471111211272110.

Turban, D.B. and Greening, D.W. (1997), "Corporate social performance and organizational attractiveness to prospective employees", Academv of Management Journal, Vol. 40 No. 3, pp. 658-672.

Waddock, S.A. and Graves, S.B. (1997), "The corporate social performance-financial performance link", Strategic Management Journal, Vol. 18 No. 4, pp. 303-319.

Walls, J.L., Berrone, P. and Phan, P.H. (2012), "Corporate governance and environmental performance: is there really a link?”, Strategic Management Journal, Vol. 33 No. 8, pp. 885-913, doi:10.1002/smj.

Wang, Z. and Sarkis, J. (2017), "Corporate social responsibility governance, outcomes, and financial performance", Journal of Cleaner Production, Vol. 162 No. 20, pp. 1607-1616, doi: 10.1016/j. jclepro.2017.06.142.

Weber, O., Scholz, R.W. and Michalik, G. (2010), "Incorporating sustainability criteria into credit risk management", Business Strategv and the Environment, Vol. 19 No. 1, pp. 39-50.

Zadek, S. (2004), "The path to corporate responsibility", Harvard Business Review, Vol. 82 No. 12, pp. 125-132.

Zellweger, T. and Sieger, P. (2012), "Entrepreneurial orientation in long-lived family firms", Small Business Economics, Vol. 38 No. 1, pp. 67-84, doi: 10.1007/s11187-010-9267-6.

\section{Further reading}

Beltratti, A. (2005), "The complementarity between corporate governance and corporate social responsibility", Geneva Papers on Risk and Insurance-Issues and Practice, Vol. 30 No. 3, pp. 373-386.

\section{About the authors}

Simona Fiandrino is a PhD Candidate in Business and Management at the University of Turin, Department of Management in Italy. The main subjects of interest are business ethics, corporate social responsibility and social finance. Simona Fiandrino is the corresponding author and can be contacted at: simona.fiandrino@unito.it

Alain Devalle is an Associate Professor of Accounting and Financial Management at the University of Turin, Department of Management in Italy. The main subjects of interest and current researches are mainly focused on corporate financial performance, corporate governance, IFRS accounting and disclosure. He has been at Northwester University Kellogg School of Management in Chicago as researcher in Corporate Finance.

Valter Cantino is a Full Professor of Accounting at the University of Turin, Department of Management in Italy. The main subjects of interest and current researches are focused on common goods and sustainable development, as well as corporate governance and disclosure.

For instructions on how to order reprints of this article, please visit our website:

www.emeraldgrouppublishing.com/licensing/reprints.htm

Or contact us for further details: permissions@emeraldinsight.com 